\title{
Diagnostic value of matrix metalloproteinase-2 and high mobility group box 1 in patients with refractory epilepsy
}

\author{
Khalid S. Salih ${ }^{1}$ (D) Farqad B. Hamdan ${ }^{2^{*}}$ (D) and Qasim S. Al-Mayah ${ }^{3}$ (D)
}

\begin{abstract}
Introduction: There are large numbers of inflammatory molecules and humoral mediators that can be involved in the epileptogenesis such as cytokines, matrix metalloproteinases (MMP), and high mobility group box-1 (HMGB1). We aimed to evaluate serum levels and the diagnostic value of MMP-2 and HMGB1 in Iraqi patients with epilepsy.

Methods: One hundred epileptic patients comprised 60 controlled epileptics and 40 refractory patients to treatment with multi antiepileptic drugs (AEDs). Other 50 family-unrelated age- and sex-matched healthy subjects were selected to represent the control group. Serum levels of MMP-2 and HMGB1 were estimated using ELISA. The receiver operating characteristic (ROC) curve was used to evaluate the diagnostic value of these markers when required.

Results: MMP-2 level was significantly higher in controls than epileptic patients in general (controlled and refractory patients). ROC curve, showed poor diagnostic value of MMP-2 in discriminating epileptics into responsive or refractory to treatment from controls ( $\mathrm{AUC}=0.679(95 \% \mathrm{Cl}=0.536-0.823)$, and $\mathrm{AUC}=0.77(95 \% \mathrm{Cl}=0.637-902)$, respectively). Serum HMGB1 level in epileptic patients and controls was in close approximation to each other.

Conclusions: MMP-2 is significantly decreased in patients particularly those with refractory epilepsy (RE); however, it has poor diagnostic value. No difference in the serum HMGB1 level between epileptic patients and controls.
\end{abstract}

Keywords: Refractory epilepsy, MMP-2, HMGB1

\section{Introduction}

Epilepsy is one of the most common chronic neurological disorders [1] with approximately one-third of affected patients are prone to refractory epilepsy (RE) with pharmacoresistance to AEDs [2].

With ensuing years, the conceptual pathophysiology of epilepsy was changed from just neuronal dysfunction into more complicated mechanisms like altered immune

\footnotetext{
* Correspondence: Farqadbhamdan@colmed-alnahrain.edu.iq; farqadbhamdan@yahoo.com

2Department of Physiology, College of Medicine, Al-Nahrain University, P.O. Box 70044, Al-Kadhimiya, St. 60, Baghdad, Iraq

Full list of author information is available at the end of the article
}

response, dysfunctional blood-brain barrier (BBB), glial dysfunction, and brain inflammation [3, 4].

Matrix metalloproteinases (MMPs) are major executors of extracellular matrix remodeling throughout the body and have complex functions under normal and pathological conditions [5]. They have been implicated in epileptogenesis, epilepsy progression, and brain remodeling after seizures, seizure-induced cell death, BBB breakdown, neuroinflammation, and aberrant synaptic plasticity [6-8].

There is ample evidence to suggest that MMPs are key players in enhancing BBB permeability in the context of brain insults and, by doing so, promoting neuroinflammation. The most abundantly expressed MMPs in the brain are MMP-2 and MMP-9 [9].

\section{Springer Open}

(c) The Author(s). 2020 Open Access This article is licensed under a Creative Commons Attribution 4.0 International License, which permits use, sharing, adaptation, distribution and reproduction in any medium or format, as long as you give appropriate credit to the original author(s) and the source, provide a link to the Creative Commons licence, and indicate if changes were made. The images or other third party material in this article are included in the article's Creative Commons licence, unless indicated otherwise in a credit line to the material. If material is not included in the article's Creative Commons licence and your intended use is not permitted by statutory regulation or exceeds the permitted use, you will need to obtain permission directly from the copyright holder. To view a copy of this licence, visit http://creativecommons.org/licenses/by/4.0/. 
It has been suggested that MMP-2 may be important in a variety of neurodevelopmental processes [10]. Moreover, MMP-2 downregulation was proposed to inhibit BBB disruption and migration of inflammatory cells into the central nervous system [11]. Recently, seizures were shown to cause MMP upregulation at the BBB that leads to degradation of tight junctions and results in barrier leakage [12].

Therefore, the downregulation of MMP-2 may be neuroprotective in patients with epilepsy. However, the precise role of MMP-2 in the pathogenesis of epilepsy remains to be established. Thus, MMP2 may be a potential epileptic biomarker for epilepsy in human serum.

High-mobility group box-1 (HMGB1), one of the damage-associated molecular patterns, is released from injured tissues [13]. The concept of HMGB1 as a biomarker of epileptogenesis and a contributor to the occurrence and persistence of seizures is growing and has been well reported [14-17].

HMGB1 exists in three isoforms each of which has distinct physiological and pathological functions: fully reduced HMGB1, disulfide HMGB1, and sulfonyl HMGB1 [18]. The disulfide form promotes seizures and cell loss [19]. One mechanism by which HMGB1 and other inflammatory cytokines may exert pro-seizure effects may be via BBB disruption by allowing them to intrude into the brain and aggravate a seizure [20].

The aim of this study is to evaluate the serum level and diagnostic value of MMP-2 and HMGB1 in the blood as a potential biomarker for the occurrence and severity of epilepsy.

\section{Methods}

A case-control study was conducted at the Epilepsy Consultation Unit, Baghdad Teaching Hospital, Medical City and the Medical Research Unit, College of Medicine, for the period from 24 Jan. 2018 to 29 Nov. 2018.

The study design was approved by the Institutional Review Board (Medical Ethics Committee) of the College of Medicine (No. mmm/60 on 08 March 2018). Written consent was obtained either from the patient or his/her parent.

\section{Subjects}

One hundred patients with either generalized tonic-clonic seizures (80), myoclonic epilepsy (10), or absence epilepsy (10) were enrolled in this study. They comprised 60 controlled and 40 refractory epileptics. The age range was 4 to 60 years (mean, $19.25 \pm 10.3$ years). They were diagnosed as epileptics by a senior specialist in neurology based on semiology, available home videos, and eyewitnesses. The patients with generalized epilepsy were on sodium valproate and levetiracetam and those with focal epilepsy were on carbamazepine and oxcarbazepine.

A patient was considered refractory for treatment if he/ she fulfilled the criteria of the ILAE Task Force which denoted drug-resistant epilepsy as the failure of adequate trials of two tolerated and appropriately chosen and used AED schedules (whether as monotherapies or in combination) to achieve sustained seizure freedom [2].

Epileptic patients with cerebrospinal fluid pleocytosis and coexisting clinical signs of meningoencephalitis (headache and fever), unclear events or cases in which there was uncertainty considering the diagnosis of seizures, severe electrolyte imbalance, another central nervous system disease at the time of specimen collection, autoimmune disease, and chronic disease like diabetes mellitus were excluded from the study.

Fifty family-unrelated age- and sex-matched subjects whose sent for causes other than epilepsy [proved to have normal magnetic resonance imaging (MRI) and electroencephalography record (EEG)] were selected to represent the control group.

\section{Methods}

Detailed clinical history and examination were done by the senior neurologist. Demographic data including age, gender, residence, family history of seizure, body mass index (BMI), and socioeconomic status were obtained. EEG was declared abnormal if pathological generalized or focal slowing was present, or if epileptiform patterns were found. Whenever needed, MRI was preferred but computed tomography was performed in patients with contraindications to MRI.

Approximately $3 \mathrm{~mL}$ of peripheral blood was collected from each participant in a plain tube from which serum was obtained and preserved at $-20^{\circ} \mathrm{C}$ until be used for measurement of serum levels of MMP-2 and HMGB1.

The serum concentration of MMP-2 and HMGB1 was assessed by commercial ELISA kits (Sangon Biotech, China) following the instructions of the manufacturer. The O.D. absorbance at $450 \mathrm{~nm}$ was read in a microplate reader, and then the concentration of MMP-2/HMGB1 was calculated.

\section{Statistical analysis}

The Statistical Package for the Social sciences (SPSS, version 25) was used for statistical analysis. Continuous data were subjected to normality test using ShapiroWilk test, and accordingly were expressed as mean (SD) and analyzed with parametric tests (if normally distributed) or as median and interquartile (IQR), and analyzed with non-parametric tests (in non-normally distributed). Categorical variables were expressed as number and percentage and analyzed with chi-square. ROC curve was used to evaluate the diagnostic value of MMP-2 in the context of discrimination between epileptic patients (whether responsive or refractory) and controls. According to this curve, the area under the curve (AUC) and cut-off of MMP-2 were calculated. A $p$ value $<0.05$ was considered statistically significant. 


\section{Results}

In Tables 1 and 2, Kruskal-Wallis test revealed no significant differences neither between the patient subgroups nor with the controls with regard to the age, gender, BMI, residence, type of epilepsy, and aggravating factors. In contrast, there were $21 \%$ of patients with a positive family history of epilepsy versus none of the controls with a highly significant difference $(p<0.001)$. Consanguinity was also more frequent among patients than controls (18\% vs. $58 \%)$ with a highly significant difference $(p<0.001)$.

The median duration of epilepsy among controlled epileptics was 10 (1-35 years) which was significantly longer $(p=0.041)$ than that of patients refractory to treatment (median $=5,1-17$ years).

Furthermore, the majority (70\%) of patients refractory to AEDs daily experienced seizure episodes, and the remaining (30\%) had these episodes 1-5 times per week. On the contrary, only $36.67 \%$ of controlled epileptics had daily seizure episodes, $25 \%$ attacked 1-5 times per month and $15 \%$ had less than one time a month with significant differences.

The cell phone as minor aggrevating factor was more frequent among the controlled epileptics than those refractory to the AEDs patients (25\% vs. $10 \%)(p=0.045)$.

Serum concentrations of both MMP-2 and HMGB1 were found to be non-normally distributed according to Shapiro-Wilk test, and accordingly, non-parametric Kruskal-Walis test as used to compare medians of these concentrations between different groups. The control group showed significantly higher MMP-2 level (median $=14.75 \mathrm{ng} / \mathrm{mL}, \mathrm{IQR}=11.73 \mathrm{ng} / \mathrm{mL}$ ) than epileptic patients $($ median $=11.92 \mathrm{ng} / \mathrm{mL}, \mathrm{IQR}=10.56)$. Likewise, the control group showed significantly higher MMP-2 level than controlled epileptics (median $=11.25 \mathrm{ng} / \mathrm{mL}$, $\mathrm{IQR}=10.19 \mathrm{ng} / \mathrm{mL}$ ) and patients refractory to treatment
$($ median $=9.0 \mathrm{ng} / \mathrm{mL}, \mathrm{IQR}=10.77 \mathrm{ng} / \mathrm{mL})$ as shown in Table 3 . However, the two patient groups were not different from each other significantly.

Serum HMGB1 level in controlled and refractory epileptics was in close approximation to each other (median $=6.8$ $\mathrm{ng} / \mathrm{mL}, \mathrm{IQR}=3.13 \mathrm{ng} / \mathrm{mL}$, and median $=6.87 \mathrm{ng} / \mathrm{mL}$, IQR $=3.34 \mathrm{ng} / \mathrm{mL}$ respectively) with no significant difference.

Median concentration of HMGB1 in controlled and refractory epileptics were $7.2 \mathrm{ng} / \mathrm{mL}(\mathrm{IQR}=4.01 \mathrm{ng} / \mathrm{mL})$ and $6.03 \mathrm{ng} / \mathrm{mL}(\mathrm{IQR}=3.36 \mathrm{ng} / \mathrm{mL})$, respectively. KruskalWallis test revealed no significant differences neither between these two groups nor with the controls (Table 3).

To find out if the MMP-2 has an independent association with epilepsy, significant variable (family history and consanguinity) between patients and controls were entered in univariate and multivariate logistic regression with MMP. Accordingly, the serum concentration of MMP-2 was categorized based on the cut-off value of $8.27 \mathrm{ng} / \mathrm{mL}$ which was obtained from ROC curve. The result showed that even in multivariate analysis, MMP-2 still has a significant association with epilepsy (Table 4).

Figure 1 shows the result of the ROC curve in the context of discrimination between epileptic patients and controls. The test revealed that the area under the curve (AUC) was $0.683,95 \% \mathrm{CI}=0.569-0797, p=0.008$. The sensitivity and specificity of the test at the cut-off value of $8.27 \mathrm{ng} / \mathrm{mL}$ were 0.73 and 0.58 respectively, indicating a poor discriminative value.

Almost similar results were obtained with this curve in the context of discrimination between controlled epileptics and the controls. The AUC was 0.679 (95\% CI = $0.536-0.823), p=0.025$. The sensitivity and specificity of the test at the cut-off value of $8.32 \mathrm{ng} / \mathrm{mL}$ were 0.72 and 0.61 respectively, indicating a low discriminative value (Fig. 2).

Table 1 Demographic and clinical characteristics of the study population

\begin{tabular}{lllll}
\hline Variables & & Control group $(\boldsymbol{n}=\mathbf{5 0})$ & Patient group $(\boldsymbol{n}=\mathbf{1 0 0})$ & $\boldsymbol{p}$ value \\
\hline Age, years & $\leq 10$ & $6(12 \%)$ & $22(22 \%)$ & 0.138 \\
& $11-20$ & $16(32 \%)$ & $39(39 \%)$ & 0.402 \\
Gender & $21-30$ & $17(34 \%)$ & $27(27 \%)$ & 0.375 \\
& $\geq 31$ & $11(22)$ & $12(12 \%)$ & 0.109 \\
Family history & Male & $23(46 \%)$ & $49(49 \%)$ & 0.729 \\
& Female & $17(34 \%)$ & $51(51 \%)$ & $<9(79 \%)$ \\
Consanguinity & Yes & $50(100 \%)$ & $21(21 \%)$ & $<0.001$ \\
Residence & No & $0(0 \%)$ & $42(42 \%)$ & 0.001 \\
BMI $\left(\mathbf{k g} / \mathbf{m}^{\mathbf{2})}\right.$ & Yes & $41(82 \%)$ & $58(58 \%)$ & $76(76 \%)$ \\
\hline
\end{tabular}


Table 2 Demographic and clinical data of epileptic patients

\begin{tabular}{|c|c|c|c|c|}
\hline \multirow[t]{2}{*}{ Variables } & & \multicolumn{2}{|c|}{ Epileptic patients on AEDs } & \multirow{2}{*}{$\begin{array}{l}p \\
\text { value }\end{array}$} \\
\hline & & Controlled $(n=60)$ & Refractory $(n=40)$ & \\
\hline \multirow[t]{4}{*}{ Age, years } & $\leq 10$ & $12(20 \%)$ & $10(25 \%)$ & 0.554 \\
\hline & $11-20$ & $28(46.67 \%)$ & $11(27.5 \%)$ & 0.054 \\
\hline & $21-30$ & $12(20 \%)$ & $15(37.5 \%)$ & 0.053 \\
\hline & $\geq 31$ & $8(13.33 \%)$ & $4(10 \%)$ & 0.615 \\
\hline \multirow[t]{2}{*}{ Gender } & Male & $28(46.67 \%)$ & $21(52.5 \%)$ & 0.568 \\
\hline & Female & $32(53.33 \%)$ & $19(47.5 \%)$ & \\
\hline \multirow[t]{2}{*}{ Family history } & No & $11(18.33 \%)$ & $10(25 \%)$ & 0.423 \\
\hline & Yes & $49(81.67 \%)$ & $30(75 \%)$ & \\
\hline \multirow[t]{2}{*}{ Consanguinity } & No & $26(43.33 \%)$ & $16(40 \%)$ & 0.741 \\
\hline & Yes & $34(65.67)$ & $24(60 \%)$ & \\
\hline \multirow[t]{3}{*}{ Type of epilepsy } & Focal & $28(46.67 \%)$ & $17(42.5 \%)$ & 0.682 \\
\hline & GTC & $21(35 \%)$ & $14(35 \%)$ & 1.0 \\
\hline & Others & $11(18.33 \%)$ & $9(22.5 \%)$ & 0.61 \\
\hline \multirow[t]{4}{*}{ Seizure frequency } & Daily & $12(20 \%)$ & $28(70 \%)$ & 0.001 \\
\hline & 1-5 times/week & $14(23.33 \%)$ & $12(30 \%)$ & 0.457 \\
\hline & 1-5 times/month & $15(25 \%)$ & $0(0 \%)$ & 0.001 \\
\hline & $<$ Once a month & $19(31.67 \%)$ & $0(0 \%)$ & 0.001 \\
\hline \multirow[t]{6}{*}{ Aggravating factors } & No specific factor & $26(43.33 \%)$ & $14(35 \%)$ & 0.405 \\
\hline & Tiredness & $10(16.67 \%)$ & $5(12.5 \%)$ & 0.568 \\
\hline & Stress & $5(8.33 \%)$ & $3(7.5 \%)$ & 0.88 \\
\hline & Sadness & $4(6.67 \%)$ & $4(10 \%)$ & 0.547 \\
\hline & Fever & $9(15 \%)$ & $4(10 \%)$ & 0.466 \\
\hline & Others (cell phone) & $6(10 \%)$ & $10(25 \%)$ & 0.045 \\
\hline \multirow{2}{*}{\multicolumn{2}{|c|}{ Duration of illness (years) }} & $5.92 \pm 4.64$ & $10.78 \pm 7.88$ & $0.041 \neq$ \\
\hline & & $5.0(1-7)$ & $10(1-35)$ & \\
\hline \multirow[t]{2}{*}{ Residence } & Urban & $43(71.67 \%)$ & $33(82.5 \%)$ & $0.214 \dagger$ \\
\hline & Rural & $17(28.33 \%)$ & 7 (17.5\%) & \\
\hline \multicolumn{2}{|l|}{ BMI $\left(\mathrm{kg} / \mathrm{m}^{2}\right)$} & $23.29 \pm 6.81$ & $23.42 \pm 7.64$ & 0.914 \\
\hline
\end{tabular}

AEDs antiepileptic drugs, GTC generalized tonic-clonic, $B M I$ body mass index

${ }^{+}$Student's $t$ test

${ }^{\ddagger}$ Mann-Whitney $U$ test

Table 3 Serum MMP-2 and HMGB1 in patients with refractory epilepsy and controls

\begin{tabular}{|c|c|c|c|c|}
\hline \multirow{2}{*}{$\begin{array}{l}\text { Biochemical } \\
\text { parameter }\end{array}$} & \multirow{2}{*}{$\begin{array}{l}\text { Controls } \\
(n=50)\end{array}$} & \multicolumn{2}{|c|}{ Epileptic patients $(n=100)$} & \multirow{2}{*}{$\begin{array}{l}p \\
\text { value }\end{array}$} \\
\hline & & Controlled $(n=60)$ & Refractory $(n=40)$ & \\
\hline MMP-2 (ng/ml) & & & & 0.036 \\
\hline Mean \pm SD & $14.69 \pm 11.54$ & $12.0 \pm 28.19$ & $5.44 \pm 6.52$ & \\
\hline Median & $14.75^{\mathrm{a}}$ & $11.25^{\mathbf{b}}$ & $9.0^{\mathbf{b}}$ & \\
\hline IQR & 11.73 & 10.19 & 10.77 & \\
\hline HMGB1 (ng/ml) & & & & 0.572 \\
\hline Mean \pm SD & $5.93 \pm 2.92$ & $6.19 \pm 4.71$ & $5.39 \pm 4.22$ & \\
\hline Median & 6.8 & 7.2 & 6.03 & \\
\hline IQR & 3.13 & 4.01 & 3.36 & \\
\hline
\end{tabular}

MMP-2 matrix metalloprotinase-2, HMGB1 high-mobility group box-1, IQR interquartile range, different small letters indicated significant differences The comparison was performed using Kruskal-Wallis non-parametric test 
Table 4 Uni- and multivariate analysis to estimate the effects of consanguinity and family history on MMP2 levels

\begin{tabular}{|c|c|c|c|c|c|c|}
\hline \multirow[t]{2}{*}{ Variables } & \multirow{2}{*}{$\begin{array}{l}\text { Controls } \\
(n=50)\end{array}$} & \multirow{2}{*}{$\begin{array}{l}\text { Patients } \\
(n= \\
100)\end{array}$} & \multicolumn{2}{|c|}{ Univariate analysis } & \multicolumn{2}{|c|}{ Multivariate analysis } \\
\hline & & & $p$ value & OR $(95 \% \mathrm{Cl})$ & $p$ value & OR $(95 \% \mathrm{Cl})$ \\
\hline Consanguinity & & & $<0.001$ & & $<0.001$ & \\
\hline No & $41(82 \%)$ & $42(42 \%)$ & & $6.29(2.76-14.33)$ & & $6.32(2.68-14.87)$ \\
\hline Yes & $9(18 \%)$ & $58(58 \%)$ & & & & \\
\hline Family history & & & $<0.001$ & & 0.016 & \\
\hline No & $50(100 \%)$ & $76(76 \%)$ & & $13.02(1.69-99.9)$ & & $12.88(1.6-103.4)$ \\
\hline Yes & $0(0 \%)$ & $21(21 \%)$ & & & & \\
\hline MMP-2 (ng/ml) & & & 0.011 & 1.0 & 0.048 & 1.0 \\
\hline$\leq 8.27$ & $36(72 \%)$ & $50(50 \%)$ & & 2.5 & & .14) \\
\hline$>8.27$ & $14(28 \%)$ & $50(50 \%)$ & & & & \\
\hline
\end{tabular}

Finally, when the epileptics refractory to AEDs compared with controls, the AUC was 0.77 (95\% CI = 0.637-902), $p=$ 0.001 . The sensitivity and specificity of the test at the cutoff value of $5.96 \mathrm{ng} / \mathrm{mL}$ were 0.88 and 0.60 respectively, indicating high sensitivity but low specificity (Fig. 3).

\section{Discussion}

The mechanisms underlying the resistance to AEDs in the epilepsy treatment are still not well-understood, although efforts to predict pharmacoresistant have revealed several risk factors such as the early onset of epilepsy, etiology, type of epilepsy, and environmental factors. Moreover, genetic variants are supposed to play an important role in the development of pharmacoresistance in patients with epilepsy [21].

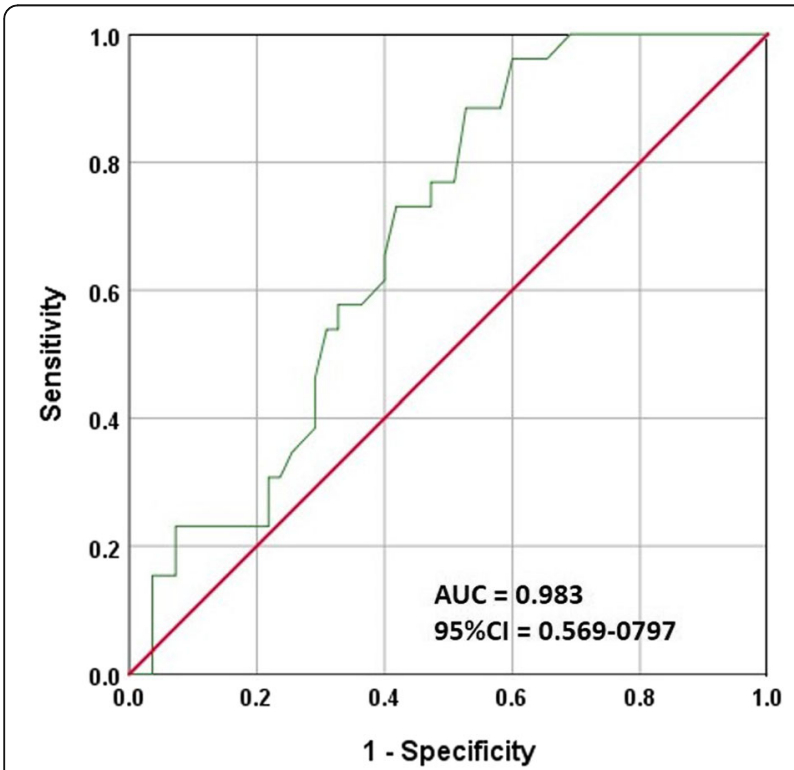

Fig. 1 Receiver operating characteristic curve of MMP-2 in the context of discrimination between epileptic patients and controls. MMP-2, matrix metalloproteinase-2
The present study revealed two significant demographic features that were associated with the occurrence of epilepsy. The first one was a family history of epilepsy and the second one which is closely related to the family history was consanguinity. Both parameters were significantly higher in epileptic patients compared to healthy control.

Detailed family history is of great value in evaluating patients with epilepsy to determine whether genetic factors contribute to its etiology. Concerning this, in the present study, approximately one-fourth of the epileptic patients have a positive family history. A similar finding was reported in Saudi Arabian epileptics where positive family history was seen in 113 patients (27\%), which was associated with earlier disease onset (15 years versus 20 years, $p$ $<0.05)$ [22] and in Jordanian epileptic children [23]. These findings are usually three- to fourfold higher than those

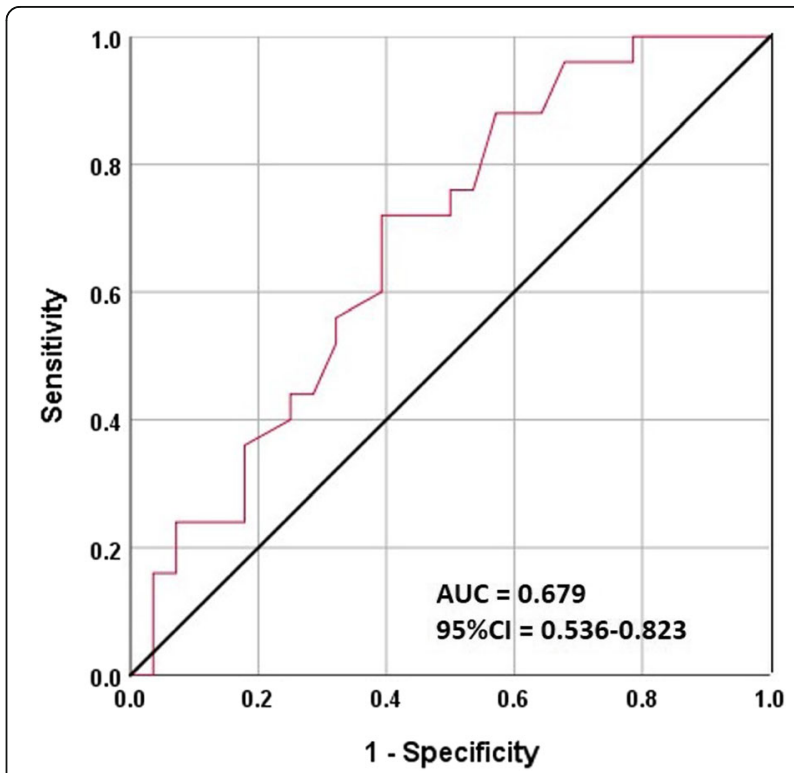

Fig. 2 Receiver operating characteristic curve for MMP-2 in the context of discrimination between controlled epileptics and controls. MMP-2, matrix metalloproteinase-2 


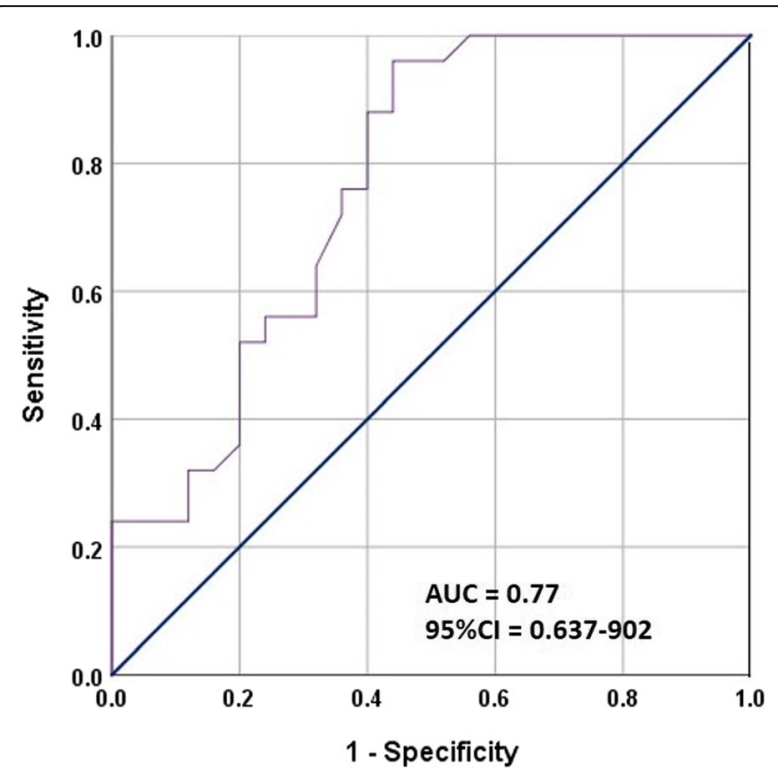

Fig. 3 Receiver operating characteristic curve for MMP-2 in the context of discrimination between epileptics refractory to treatment and controls. MMP-2, matrix metalloproteinase-2

reported in Italian as well as Turkish epileptic patients $[24,25]$. This may be related to a high incidence of consanguineous marriage reported in Arabian countries.

A family history of epilepsy was found to be a strong predictor of epilepsy in a population-based case-control study by Kannoth and his group [26] and it increased the risk to develop both generalized- and localization-related epilepsies. On the other hand, Khan and coworkers [27] found no association between parental consanguinity and epilepsy in a population known to have high rates of this marital habit, yet the family history of epilepsy was documented in more than half of the cases.

The role of parental consanguinity in epilepsy was evaluated in a piece of literature, aiming to determine whether it is a risk factor for epilepsy. Asadi-Pooya [28] examined Iranian children with epilepsy and found a significantly higher percentage of parental consanguinity in these patients when compared to the general population, and he concluded that parental consanguinity was a potential risk factor for epilepsy.

Parental consanguinity can raise the presumption of an autosomal recessive disease. The availability of a family pedigree provides an opportunity to counsel unaffected family members concerning their own risk for having the disease or for carrying the abnormal gene. A maternal inheritance pattern may be a clue to an X-linked disorder, such as Menkes' syndrome, or the transmission of a defect in mitochondrial DNA, as in mitochondrial encephalomyopathy, lactic acidosis, and stroke-like episodes [29].

In recent years, MMPs have gained significant attention for their possible roles in epileptogenesis and kindled seizures [30]. For this reason, serum MMP-2 was determined in this study and was significantly different between epileptic patients and control groups and was higher in the control compared to the patients. These results were consistent with that of Wang et al. [5] who demonstrated diminished serum MMP-2 levels in patients with epilepsy and Soliman et al. [31] who demonstrated decreased serum MMP-2 levels in those patients especially those with focal seizures.

A possible explanation for this decrement in the serum MMP-2 compared to high enzymatic activity in brain tissue is the consumption of peripheral MMP-2 and shifting into the brain to share in the process of epileptogenesis. Such a hypothesis is worth future studies using both serum and animal brain tissue sampling [31].

The role of MMP-2 was evaluated in a variety of neurodevelopmental processes and neurological disorders, but little is known about its precise role in the pathogenesis of epilepsy [10]. It was suggested that the downregulation of MMP-2 might inhibit BBB breakdown and migration of inflammatory cells into the central nervous system [11].

In the current study, the level of MMP-2 was found to be lower in epileptic patients especially those who are refractory to treatment. MMP-2 is involved in the repair process following central nervous system injury and its upregulation in neurologic conditions might have a negative impact. Therefore, the downregulation of MMP-2 may be neuroprotective in patients with epilepsy. However, the precise role of MMP-2 in the pathogenesis of epilepsy remains to be established [31].

To evaluate the utility of MMP-2 levels in discriminating cases of epilepsy (controlled and refractory epileptics) from normal controls, ROC curve analysis was performed. At a cut-off value of MMP-2 concentration of $8.27 \mathrm{ng} / \mathrm{ml}$, the sensitivity and specificity for distinguishing epileptic from control subjects were $73 \%$ and $58 \%$, respectively, and the AUC was 0.683 .

Several previous studies do investigate the diagnostic value of this marker in detection epilepsy. Wang et al. [5] showed that at a higher cut-off value of $175.40 \mathrm{ng} / \mathrm{ml}$ for MMP-2 concentration, the sensitivity and specificity for distinguishing epileptic from control subjects was 71.13\% and $62.66 \%$, respectively, and the AUC was 0.697 . At an even higher cut-off value of MMP-2 concentration of $111.5 \mathrm{ng} / \mathrm{ml}$, the sensitivity and specificity for distinguishing epileptic from control subjects were $85.29 \%$ and 97.06\%, respectively, and the AUC was 0.922 [31].

Furthermore, with a cut-off value of MMP-2 concentration of $5.96 \mathrm{ng} / \mathrm{ml}$ (lower than that of the current study), the sensitivity and specificity for distinguishing patients with RE from the control subjects were $88 \%$ and $60 \%$, respectively, and the AUC was 0.77 . Hence, MMP2 can be considered a very beneficial diagnostic biomarker for RE with a valuable sensitivity and specificity. 
Several clinical studies have reported that serum HMGB1 levels are elevated in patients with infection and/or systemic inflammatory response syndrome than in healthy control individuals [32]. HMGB1 is involved in various diseases without obvious infections; for example, rheumatoid arthritis, hemorrhagic shock, cerebral and myocardial ischemia, acute lung injury, and acute pancreatitis [33].

HMGB1 is highly expressed in the human epileptogenic brain, and antagonists of HMGB1 have been demonstrated to retard seizure precipitation and to decrease acute and chronic seizure recurrence in epilepsy animals [34].

In a study conducted by Choi et al. [33], serum levels of HMGB1 were significantly higher in febrile seizure patients (being $9.0 \mathrm{ng} / \mathrm{mL}$ in afebrile controls, $24.8 \mathrm{ng}$ / $\mathrm{mL}$ in febrile control, and $30.1 \mathrm{ng} / \mathrm{mL}$ in an afebrile patient refractory to AEDS with status epilepticus attack). An analogous rise in the total HMGB1 serum concentration after seizures also reported in those refractory to AEDs treatment compared to healthy controls $(8.6 \mathrm{ng} /$ $\mathrm{mL} \pm 3.5$ versus $0.7 \pm 0.3, p<0.002)$ and in patients with epilepsy who had been seizure-free for more than 6 months $(8.6 \pm 3.5$ versus $1.25 \pm 0.71, p<0.0001)$ [35].

However, the present study revealed a statistically nonsignificant difference in the serum HMGB1 levels in patients with epilepsy as compared to normal healthy subjects and between controlled and refractory epileptics.

Several assumptions can explain these non-significant results in the current study. Firstly, the timing of HMGB1 measuring can significantly influence the result. Immunoblot analysis suggests that HMGB1 was induced in the hippocampi region in the kainic acid-induced model; it peaked twice at $3 \mathrm{~h}$ and 6 days after-kainic acid administration. The significant amount of HMGB1 was accumulated in serum at $12 \mathrm{~h}$ post-kainic acid which might be due to HMGB1 release due to kainic acid-induced neuronal death [36].

In another study, in a kainic acid-induced epilepsy model, the HMGB1 expression level in the epileptic group was lower as compared to the control group $(p<0.05)$ at $24 \mathrm{~h}$ and increased compared to the control group at $72 \mathrm{~h}$ $(p<0.05)$. These findings generally support the notion that there are HMGB1 translocation and release in the CA1 and cerebral cortex area during an acute epileptic state [37]. Thus, measuring HMGB1 in arbitrary time may not reflect the actual concentration of this mediator in epileptic patients and such measurement should be timed within a limited period after seizure. Secondly, there are several isoforms of HMGB1 (acetylated, nonacetylated, disulfide, reduced, and oxidized). It has been shown that each isoform has its expression and activity. For example, disulfide HMGB1 is early expressed in patients with newly diagnosed epilepsy, and its persistence was associated with subsequent seizures. In contrast, acetylated, disulfide HMGB1 isoforms are persistently expressed in chronic, drug-refractory epilepsy [38]. It is well known that the
ELISA technique measures the total HMGB1 regardless of the isoforms. Therefore, the presence of a high concentration of certain isoforms with the absence of other isoforms can give misleading results about the total HMGB1. Finally, there are different producers for HMGB1, i.e., neuronal, glial, and endothelial cells of the central nervous system as well as from circulating leukocytes [39]. The HMGB1 produced from circulating leukocytes seems to have no association with that produced as a result of brain insult. As such, other comorbidities may influence (increases or decreases) the production of HMGB1 from leukocyte which certainly influences the final measurement with ELISA.

In conclusion, MMP-2 decreased significantly in the serum of patients particularly those with RE; however, it has poor diagnostic value, and serum levels of HMGB1 do not always undergo significant alteration in controlled or refractory epileptics.

\section{Abbreviations \\ AEDs: Antiepileptic drugs; AUC: Area under the curve; BBB: Blood-brain barrier; BMI: Body mass index; EEG: Electroencephalography; HMGB1: High mobility group box-1; IQR: Interquartile; MMP: Matrix metalloproteinases; MRI: Magnetic resonance imaging; RE: Refractory epilepsy; ROC: Receiver operating characteristic}

\section{Acknowledgements}

We thank Professor Dr. Akram Al-Mahdawi (Iraqi Board for Medical Specialization/Neurology) for examining and referring the patients with epilepsy.

\section{Settings}

Epilepsy Consultation Unit, Baghdad Teaching Hospital, Medical City, and the Medical Research Unit, College of Medicine, Al-Nahrain University, Baghdad, Iraq.

\section{Authors' contributions}

All the authors have directly participated in the preparation of this manuscript and have approved the final version submitted. K.S.S. contributed to the collection of cases. Q.S.A. performed statistical analysis. K.S.S. drafted the manuscript. F.B.H. and Q.S.A. conceived the study and participated in its design and interpretation. F.B.H. and Q.S.A. supported manuscript drafting. All the authors have read and approved the final manuscript.

\section{Funding}

Self-funding

\section{Availability of data and materials}

All data generated or analyzed during this study are included in this published article. The datasets used and/or analyzed during the current study are available from the corresponding author on reasonable request.

\section{Ethics approval and consent to participate}

The study design was approved by the Institutional Review Board-IRB of the College of Medicine/Al-Nahrain University (Decision No. mmm/60; date: 08 March 2018). An informed written consent was obtained from all participants.

Consent for publication

Not applicable

Competing interests

The authors declare that they have no competing interests. 


\section{Author details}

${ }^{1}$ College of Pharmacy, Tikrit University, Tikrit, Iraq. ${ }^{2}$ Department of Physiology, College of Medicine, Al-Nahrain University, P.O. Box 70044, Al-Kadhimiya, St. 60 , Baghdad, Iraq. ${ }^{3}$ Medical Research Unit, College of Medicine, Al-Nahrain University, Baghdad, Iraq.

Received: 22 May 2020 Accepted: 8 October 2020

Published online: 19 October 2020

\section{References}

1. Hesdorffer D, Logroscino G, Benn E, Katri N, Cascino G, Hauser W. Estimating risk for developing epilepsy: a population-based study in Rochester, Minnesota. Neurology. 2011;76(1):23-7. https:/doi.org/10.1212/WNL.0b013e318204a36a.

2. Kwan P, Brodie MJ. Definition of refractory epilepsy: defining the indefinable? Lancet Neurol. 2010;9(1):27-9. https://doi.org/10.1016/S1474-4422(09)70304-7.

3. Heinemann U, Kaufer D, Friedman A. Blood-brain barrier dysfunction, TGF beta signaling, and astrocyte dysfunction in epilepsy. Glia. 2012;60(8):12517. https://doi.org/10.1002/glia.22311.

4. Sada N, Lee S, Katsu T, Otsuki T, Inoue T. Epilepsy treatment: targeting LDH enzymes with a stiripentol analog to treat epilepsy. Science. 2015;347(6228): 1362-7. https://doi.org/10.1126/science.aaa1299.

5. Wang R, Zeng GQ, Tong RZ, Zhoua D, Hong Z. Serum matrix metalloproteinase-2: a potential biomarker for diagnosis of epilepsy. Epilepsy Res. 2016;122:114-9. https://doi.org/10.1016/j.eplepsyres.2016.02.009.

6. Wilczynski GM, Konopacki FA, Wilczek E, Lasiecka Z, Gorlewicz A, Michaluk P, et al. Important role of matrix metalloproteinase 9 in epileptogenesis. J Cell Biol. 2008;180(5):1021-35. https://doi.org/10.1083/jcb.200708213.

7. Yang Y, Hill JW, Rosenberg GA. Multiple roles of metalloproteinases in neurological disorders. Prog Mol Biol Transl Sci. 2011;99:241-63. https://doi. org/10.1016/B978-0-12-385504-6.00006-3.

8. Rempe RG, Hartz AMS, Bauer B. Matrix metalloproteinases in the brain and blood-brain barrier: versatile breakers and makers. J Cereb Blood Flow Metab. 2016;36(9):1481-507. https://doi.org/10.1177/0271678X16655551.

9. Ikonomidou C. Matrix metalloproteinases and epileptogenesis. Mol Cell Pediatr. 2014;1:6. https://doi.org/10.1186/s40348-014-0006-y.

10. Verslegers M, Lemmens K, Van Hove I, Moons L. Matrix metalloproteinase-2 and -9 as promising benefactors in development, plasticity and repair of the nervous system. Prog Neurobiol. 2013;105:60-78. https://doi.org/10.1016/j. pneurobio.2013.03.004

11. Mirshafiey A, Asghari B, Ghalamfarsa G, Jadidi-Niaragh F, Azizi G. The significance of matrix metalloproteinases in the immunopathogenesis and treatment of multiple sclerosis. Sultan Qaboos Univ Med J. 2014;14(1):e1325 https://www.ncbi.nlm.nih.gov/pubmed/24516744

12. Rempe RG, Hartz AMS, Soldner ELB, Sokola BS, Alluri SR, Abner EL, Kryscio RJ, Pekcec A, Schlichtiger J, Bauer B. Matrix metalloproteinase-mediated blood-brain barrier dysfunction in epilepsy. J Neurosci. 2018;38(18):4301-15. https://doi.org/10.1523/JNEUROSCI.2751-17.2018.

13. Mazarati A, Maroso M, lori V, Vezzani A, Carli M. High-mobility group box-1 impairs memory in mice through both toll-like receptor 4 and receptor fo advanced glycation end products. Exp Neurol. 2011;232:143-8. https://doi. org/10.1016/j.expneurol.2011.08.012.

14. Huang JS, Wu Y, Huang Q, Li SJ, Ye JM, Wei X, et al. Expression level and distribution of HMGB1 in Sombati's cell model and kainic acid-induced epilepsy model. Eur Rev Med Pharmacol Sci. 2015;19:2928-33 PMID: 26241550.

15. Walker LE, Janigro D, Heinemann U, Riikonen R, Bernard C, Patel M. WONOEP appraisal: molecular and cellular biomarkers for epilepsy. Epilepsia. 2016;57(9):1354-62. https://doi.org/10.1111/epi.13460

16. Ravizza T, Terrone G, Salamone A, Frigerio F, Balosso S, Antoine DJ, et al. High mobility group box 1 is a novel pathogenic factor and a mechanistic biomarker for epilepsy. Brain Behav Immun. 2018;72:14-21. https://doi.org/ 10.1016/j.bbi.2017.10.008

17. Paudel YN, Shaikh M, Serrano AA, Kumari Y, Aleksovska K, Alvim MKM, et al. HMGB1: a common biomarker and potential target for TBI, neuroinflammation, epilepsy and cognitive dysfunction. Front Neurosci. 2018;12:628. https://doi.org/10.3389/fnins.2018.00628.

18. Aucott $H$, Lundberg J, Salo H, Klevenvall L, Damberg P, Ottosson L, et al. Neuroinflammation in response to intracerebral injections of different HMGB1 redox isoforms. J Innate Immun. 2018;10(3):215-27. https://doi.org/ 10.1159/000487056.

19. Balosso S, Liu J, Bianchi ME, Vezzani A. Disulfidecontaining high mobility group box-1 promotes $\mathrm{N}$-methyl-D-aspartate receptor function and excitotoxicity by activating Toll-like receptor 4-dependent signaling in hippocampal neurons. Antioxid Redox Signal. 2014:21(12):1726-40.

20. Gorter JA, van Vliet EA, Aronica E. Status epilepticus, blood-brain barrier disruption, inflammation, and epileptogenesis. Epilepsy Behav. 2015;49:13-6.

21. Manna I, Gambardella A, Labate A, Mumoli L, Ferlazzo E, Pucci F, et al. Polymorphism of the multidrug resistance 1 gene MDR1/ABCB1 C3435T and response to antiepileptic drug treatment in temporal lobe epilepsy. Seizure. 2015;24:124-6.

22. Babtain FA. Impact of a family history of epilepsy on the diagnosis of epilepsy in Southern Saudi Arabia. Seizure. 2013;22(7):542-7.

23. Daoud AS, Batieha A, Bashtawi M, El-Shanti H. Risk factors for childhood epilepsy: a case-control study from Irbid, Jordan. Seizure. 2003;12:171-4

24. Bianchi A, Viaggi S, Chiossi E, LICE Episcreen Group. Family study of epilepsy in first degree relatives: data from the Italian Episcreen Study. Seizure. 2003; 12(4):203-10.

25. Huseyinoglu N, Ozben S, Arhan E, Palanci Y, Gunes N. Prevalence and risk factors of epilepsy among school children in eastern Turkey. Pediatr Neurol. 2012;47(1):13-8

26. Kannoth S, Unnikrishnan JP, Santhosh Kumar T, Sankara Sarma P, Radhakrishnan K. Risk factors for epilepsy: a population-based case-control study in Kerala, southern India. Epilepsy Behav. 2009;16(1):58-63.

27. Khan H, Mohamed A, Al-Sakini Z, Zulfiquar K, Sohail A, Shaikh RB, et al. Consanguinity, family history and risk of epilepsy: a case-control study. Gulf Med J. 2012;1(1):32-6.

28. Asadi-Pooya AA. Epilepsy and consanguinity in Shiraz, Iran. Eur J Paediatr Neurol. 2005:9(6):383-6.

29. Kolodny EH. Metabolic and genetic disorders. In: Devinsky O, Westbrook LE, editors. Epilepsy and Developmental Disabilities. Boston: ButterworthHeinemann; 2001. p. 17-22.

30. Mizoguchi $\mathrm{H}$, Yamada K. Roles of matrix metalloproteinases and their targets in epileptogenesis and seizures. Clin Psychopharmacol Neurosci. 2013;11(2):45-52.

31. Soliman AM, El Ebeary ME, Abdel Rahman TG, Ebied AA. Serum matrix metalloproteinase-2 as a biomarker for diagnosis of idiopathic epilepsy. Zagazig Univ Med J. 2019;25(1):155-63.

32. Van Zoelen MA, Laterre PF, van Veen SQ, van Till JW, Wittebole X, Bresser P, et al. Systemic and local high mobility group box 1 concentrations during severe infection. Crit Care Med. 2007;35(12):2799-804.

33. Choi J, Min HJ, Shin JS. Increased levels of HMGB1 and pro-inflammatory cytokines in children with febrile seizures. J Neuroinflammation. 2011;8:135.

34. Maroso M, Balosso S, Ravizza T, Liu J, Aronica E, lyer AM, et al. Toll-like receptor 4 and high mobility group box-1 are involved in ictogenesis and can be targeted to reduce seizures. Nat Med. 2010;16(4):413-9.

35. Walker LE, Tse K, Ricci E, Thippeswamy T, Sills GJ, White SH, et al. High mobility group box 1 in the inflammatory pathogenesis of epilepsy: profiling circulating levels after experimental and clinical seizures. Lancet. 2014:383:S105.

36. Luo L, Jin Y, Kim D, Lee JK. Glycyrrhizin attenuates kainic acid-induced neuronal cell death in the mouse hippocampus. Exper Neurobiol. 2013;22(2):107-15.

37. Fu L, Liu K, Wake H, Teshigawara K, Yoshino T, Takahashi H, et al. Therapeutic effects of anti-HMGB1 monoclonal antibody on pilocarpineinduced status epilepticus in mice. Sci Rep. 2017;7(1):1179.

38. Walker LE, Frigerio F, Ravizza T, Ricci E, Tse K, Jenkins RE, et al. Molecular isoforms of high-mobility group box 1 are mechanistic biomarkers for epilepsy. J Clin Invest. 2017;127(6):2118-32.

39. Walker LE, Griffithsb MJ, McGillb F, Lewthwaitee P, Sillsa GJ, Jorgensena A, et al. A comparison of HMGB1 concentrations between cerebrospinal fluid and blood in patients with neurological disease. Biomarkers. 2017;22(7):635-42.

\section{Publisher's Note}

Springer Nature remains neutral with regard to jurisdictional claims in published maps and institutional affiliations. 